\title{
FEATURES OF BILINGUAL APPROACH \\ APPLICATION IN SPECIAL INSTITUTIONS FOR \\ DEAF IN UKRAINE
}

\author{
Svitlana Kulbida, Dr. Sc., Prof. \\ research officer of Sign Language Training, \\ Mykola Yarmachenko Institute \\ of Special Pedagogy and Psychology, \\ National Academy of Educational Sciences of Ukraine, \\ Kyiv, Ukraine \\ svk5554@gmail.com \\ https://orcid.org/0000-0002-0194-3495
}

To cite this article: Kulbida, S. (2019). Features of bilingual approach application in special institutions for deaf in Ukraine. Education: Modern Discourses, 2, 55-64. https://doi.org/

Abstract. All levels of the deaf educational system in Ukraine demonstrate the gradual development of humanitarization and humanization in terms of compliance with international standards for observing rights in the application of the national sign language, positive experience in using bilingual educational programs with the active usage of the Ukrainian language and Ukrainian sign language.

The features of application the bilingual approach are supported by documents of the regulatory framework (the Law "On Education", Regulations on a special school and educational rehabilitation center).

Appropriate in this context is the development of key competences during the schooling of deaf students who recognize and use the skills of the deaf in sign language. Sign-speaking communicative competence is considered as the key competency, presented in modern development. The content aspect of sign-speaking communicative competence development is discovered on the example of "Dialogue speech development" is revealed and a wide range of language competences is presented.

The practical implementation in the activities of special institutions, individual pedagogical workers who own Ukrainian Sign language (USL), representatives of public organizations as the Ukrainian Deaf Society, The Association of Deaf Educators who promote the implementation of bilingualism, since they are based on the achievements of two languages, that are considered not as a problem, an obstacle, but as a resource for enrichment, taking into account the compensatory capabilities, abilities of each deaf student are presented.

The presented complexity is reflected in the educational standards of the New Ukrainian School, which are being implemented in Ukraine.

Key words: bilingual approach; deaf student; key competencies; regulatory framework; signspeaking communicative competence; special institutions; Ukrainian Sign language.

\section{INTRODUCTION. PROBLEM STATEMEN}


Unstoppable development of humanitarization and humanization in the educational space of Ukrainian society, the filling of the information component in the content and forms of communicative activity in the context of present-day realities create the need to improve the general education at all levels of the education system of the deaf. The humanist and linguistic component occupy a rather significant place in these controlled processes as it motivates using the bilingual approach (Ukrainian language and Ukrainian Sign language), as well as provides the formation of key oral communicative competence as well as ensures the formation of key sign-speaking communicative competence (S-SCC) - the necessary linguistic and socio-cultural component of development (Baykina \& Kul'bida, 2014; Ivanyusheva \& Kul'bida, 2013, 2016-2019; Zasenko, 2015). This component provides not only the humanitarian development of a deaf person, but also the mastering of the necessary universal communicative toolkit that is the basis for:

- its organic existence in the information space not only of the deaf community, but also of the community of those who are hearing;

- mastering the contacting languages in convenient and accessible forms at all stages of learning;

- for realizing his/her role, place, significance in society on the level with other peers.

Today, there is a wide range of benefits to learning two languages. And this does not relate to the number of languages used when forming key competences in languages, but how these competences should be developed in the first five years in order to successfully develop, taking into account the capabilities, needs, abilities and sensory periods of each student with special educational needs. The advanced repertoire in two languages will improve the necessary grading levels of competence that are not necessarily the same in each context. Such a potential asset is part of the social, speech, linguistic, cultural experience of each deaf student, and the basis for the development of further competences. Educational goal in each level of education should take into account the level of such competences and on this basis, to build the 
student's advance in the zone of future development in the study of educational disciplines.

It is clear that the proposed bilingualism creates absolutely new challenges for the education system. The level of support, the recognition of bilingualism, its benefits will undoubtedly affect educational programs, strategies, pedagogical technologies, language portfolios.

\section{LITERATURE REVIEW}

Important for our study were the achievements of foreign colleagues in understanding the status of national sign languages and their role in the educational development of a deaf child (Johnston \& Schembri, 2007; Meir \& Sandler, 2007; Kyle \& Woll, 1985; Klima \& Bellugi, 1979, 1991; Padden \& Humphries, 1988; Zaytseva \& Davydenko, 2009; Dymskys, 2006; Krayevsky, 1964; Frumkima, 1989; Stokoe, 1970). Fundamental questions about the required role of the sign language in early access to the language and its effects on the organization and development of the brain are disclosed in the studies of Mayberry (2002), Chamberlain C., Mayberry (2008), R. Storep (2018), A. Te (2018), S. Tashjian (2018), Neville, Bavelier, Corina et al.,

(1998), Padden C, Ramsey C. (2000), Humphries, T., Bauman H-D. (2008), Stewart D., Clarke (2003) and others.

Much attention is paid to our understanding of the meaning of the term "speech deprivation in the deaf" with the using of language in the critical period that was highlighted by P. Kushalnagar, G. Mathur, D. Napoli, C. Padden, C. Rathmann, S. Smith, 2012. Ignoring the language and especially using the sign language - a convenient and easy means of communication in this period - leads to irreversible consequences not only speech and language development, but also the affected cognitive activity, which will be based on the basis of the first imperfect language. Such scientists as Wilbur R., 2001, Chamberlain C., Mayberry R., 2008, Strong M., Prinz P., 2000, Padden C., Ramsey C. 2000 and others associated speech deprivation in the deaf with the mastery of a lower level of literacy and the limited sign-speaking communicative competence as educational advancement of deaf students after a critical 
period, which can not but cause deep concern (Chamberlain \& Mayberry, 2008; Padden \& Ramsey, 2000; Wilbur, 2001). Considering this aspect we have focused on the bilingual principles of educational development of the deaf (verbal and sign language). To help with this issue, we needed researches of Moores D. (2001) the educational development of the deaf, where the principles and practice of the use of two languages from psychological positions are revealed; Kobel I. (2005) the experience review of bilingual education in North America (Rassel, 2004; Wilbur, 2001; Chamberlain \& Mayberry, 2008; Leal, 2005; Mason, 1995). In particular, Czubek (1999-2004) is practicing a bilingual curriculum - ASL \& English (Czubek, 2007; Czubek, 2009). Bilingualism takes into account the individual levels of sign-speaking communicative competence in ASL, on the basis of which the English language is consciously studied. The fluency in both languages is vital and complementary.

It should be emphasized that the Ukrainian experience of studying the issue of bilingualism of the deaf is represented by scientists and representatives of the public organization UTOG and has the achievements in the form of Project of the Concept of Sign language in Ukraine (Kulbida \& Chepchina, 2009), Concepts of bilingual education (2011), implemented programs for the studying of USL, sign dictionaries, manuals, articles, which highlights the peculiarities of the bilingual approach application. In particular, in the author's development of sign-speaking communicative competence (Kulbida, 2016), a linguodidactic model of USL mastering with the stepby-step levels of competencies from the preparatory, the first to the 12th grade was substantiated (Ivanyusheva \& Kul'bida, 2013; Kulbida, 2018; Sadova, Fedorchenko \& Muzhaylo, 2017; Tkachenko \& Kul'bida, 2014).

\section{METHODOLOGY}

The methodological basis for presenting the research results in the materials of the article is:

- the position of education modern philosophy of Ukraine regarding the consideration the idea of the dialogical development of culture as a human 
communication way with the aspiration for mutual understanding (Zyazyun, 2000; Kremen, 2008; Mamchur, 2012 and others);

- conceptual provisions on the orientation of the educational process on the personal development of students with special educational needs (Bondar, 2004; Degtyarenko, 2010; Dmytriyeva, 2016; Zasenko, 2018; Kobel, 2004; Kolupayeva, 2018; Kulbida, 2019; Pahomova, 2017; Syn’ov, 2016; Suprun, 2017; Taranchenko, 2018; Sheremet, 2019 and others);

- the main provisions of the system approach as a methodological method of learning pedagogical facts, the process that involves a set of elements of the study of deaf children in the process of their communication, learning, structural and specificity of the educational process (Baykina, 2015; Dymskys, 2010; Zaytceva, 2010; Zasenko, 2016; Ivanyusheva, 2014; Yu. Kramar, 2010; Kulbida, 2016-2019; Lytovchenko, 2015; Lyahova, 2010; Malynovych, 2009; Puschyn, 2008; M. Savchenko, 2017; O. Savchenko, 2014 and others);

- the doctrine of the socio-cultural development of the personality of the deaf student, conceptual provisions of the sign language in Ukraine, bilingual education for hearing impaired persons (Adamyuk, 2015; Ye. Gryschenko, 2014; Zborovska, 2016; Ivanyusheva, 2019; Kamenska, 2006; Kulbida, 2018; Chepchina, 2018 and others).

\section{MAIN RESULTS}

The educational development of the deaf is carried out mainly in the system of special institutions of general secondary education, which has traditionally been formed in Ukraine for many decades, using only a monolingual approach of verbal (oral, written, dactyl alphabet) forms without the usage of sign language. An uneasy way of one-language education without taking into account the sensitive periods of language and speech development that has come to our inheritance during the last century has certainly affected the intellectual, speech and linguistic achievements of adult deaf people. Many foreign researchers rightly emphasize the importance of developing a language of useful format in the first five years of life, regardless of whether the is a language sign or verbal, without prejudice to the development of any 
language with any modality (Mason, 1995; Schick, 2003). The foundations for such development of a deaf person are formed from the preschool age, and later - in primary school, and mainly in the process of communicative activity, which requires the mastery of not only a certain set of linguistic concepts and facts, their understanding, comparing, comparison etc. in two languages, but also synthetic and analytical skills to plan, the development of ideological ideas, the formation of personal qualities of the deaf student as a subject of learning.

Over the last ten years we have seen some positive changes in the educational sphere, including for deaf people. Among them are significant: the cancellation of the transition to a 12-year term of study, discussion of a broad public and the adoption of new standards for primary education - New Ukrainian School, the introduction of new content lines to the educational industry "Technologies", in particular familiarization with information and communication technologies, selection and testing of textbooks of the modern generation from various subjects that are allowed to be used in the educational process, the introduction of compulsory study of the Ukrainian Sign language from grades 1 to 12 , and from grade 5 - a foreign language (Ministry of Education, 2016).

There is no doubt that the basis for such innovations is the regulatory framework, which took into account the situation: Convention on the Rights of Persons with Disabilities, scientific researches of the Mykola Yarmachenko Institute of Special Pedagogy and Psychology, National Academy of Educational Sciences of Ukraine: Project of Concept of Sign Language in Ukraine (2009), Concepts on bilingual education in Ukraine (Kulbida \& Chepchyna, 2009), Organizational and methodological conditions of the USL cabinet in the general secondary schools for deaf (Tkachenko \& Kul'bida, 2014) and the wishes of civic organizations.

Thus, the Law "On education”, adopted in 2017 (Art. 7) guarantees to persons with hearing impairment the right to learn a sign language and to study the Ukrainian sign language (Verkhovna Rada of Ukraine, 2017: p. 3). Article 12 proclaims the formation of key competences, as well as the free possession of the state language, and the ability to communicate with their native (in the case of a difference from the state) 
(Verkhovna Rada of Ukraine, 2017: p. 4). Paragraph 5 draws attention to the acquisition of persons with special educational needs of primary education from another age, and the duration of their acquisition of "primary and basic secondary education may be extended with the addition of the educational program correctiondevelopment component" (Verkhovna Rada of Ukraine, 2017: p. 5). The specifics of obtaining such persons full secondary education are determined by a special law.

Preparation of a special law - a matter of time, although some provisions already exist. In particular, the Regulation on a special school approved this year (Ministry of Education and Science of Ukraine, 2019: p. 1), states that:

a) special schools for children with hearing impairments are created;

b) paragraph 47 specifies the features of correction and development work aimed at "maximum preservation and development of residual hearing, formation of pronunciation, the development of oral speech of children with monitoring of the dynamics of their auditory function, compensatory development using the Ukrainian sign language, bilingual approach to quality mastering of educational material from all subjects (disciplines)" (Verkhovna Rada of Ukraine, 2017: p. 2).

c) in paragraph 57 the attention is focused on the creation of a department of correction and developmental work comprises, among other classrooms and the USL classroom (Verkhovna Rada of Ukraine, 2017: p. 3).

Innovations in regulatory support is important in terms of providing equal educational conditions, creating conditions for students with hearing impairments with different competences in the first, second language of studying, in supporting the gradual development of literacy skills and using opportunities to grow with hearing peers. The use of a bilingual approach to quality learning of all subjects (disciplines) with effective teaching has a significant potential in achieving students with gradual levels of sign-speaking communicative competence, simultaneously raising the sociocultural component.

The aforementioned aspect represents the observance of the fundamental rights of deaf and hard of hearing citizens, as proclaimed in the Brussels Declaration (2010) on sign languages of the European Union. According to a member of the European 
Parliament and the European Union of the Deaf Dr. Adam Costa: "Users of sign language have equal fundamental rights as other citizens of the European Union. They, as citizens with special educational needs, are not only users but also keepers of local national sign languages, are endowed with equal rights on a par with other linguistic and cultural minorities" (Krausneker, 2008: p. 243).

Today, there is a wide range of benefits to learning two languages. And this does not relate to the number of languages used when forming key competences in languages, but how these competences should be developed in the first five years in order to successfully develop, taking into account the capabilities, needs, abilities and sensory periods of each student with special educational needs. The advanced repertoire in two languages will improve the necessary grading levels of competence that are not necessarily the same in each context. Such a potential asset is part of the social, speaking, linguistic, cultural experience of each student with hearing impairment and the basis for the further competence development. Educational goal in each level of education should take into account the levels of such competences and on this basis build further student advancement into the zone of future development in the study of educational disciplines.

Among such compulsory competences the leading role is played by those who position USL as an obligatory component of the linguistic and socio-cultural society achievements of tolerance, integrity, democracy, as well as the achievements of gradual social progress that are associated with the humanitarian, informational and intellectual development of the deaf in the educational process of special institutions of general secondary education.

A fundamental and timely issue is the reorientation of the conceptual and substantive aspects of the activities of those modern aspects of competence, among which sign-speaking communicative competence is significant, which is, of course, relevant and in demand in the practice of special institutions of general secondary education of deaf persons. Theoretical basis of sign-speaking communicative competence is highlighted in the works of Ivanyusheva N., Kulbida S., Chepchina I., Tkachenko K., Zborovska N. from 2012 to 2019 years (Chepchyna, 2018; Ivanyusheva 
\& Kul'bida, 2013; Kulbida, 2016; Kulbida \& Chepchyna, 2009; Tkachenko \& Kul'bida, 2014). We present a separate aspect of the lingual didactic model of the formation the sign-speaking communicative competence.

An example of "Dialogue speech development" is given in three directions (dialogical replicas, understanding the social roles and using in forms of communication, producing dialogical texts on topics) with specific skills of signspeaking communicative competence from pre-school, from the first to the twelfth grade (Table 1).

Table 1.

"Dialogue speech development" (three directions)

\begin{tabular}{|c|c|c|c|c|}
\hline & Pre-school & 1 & 2 & 3 \\
\hline \multicolumn{5}{|c|}{ Dialogical replicas development } \\
\hline . & $\begin{array}{l}\text { Skills on a mentor's } \\
\text { model and by } \\
\text { oneself to greet, to } \\
\text { say goodbye, to } \\
\text { refer to and to } \\
\text { respond to them. } \\
\text { Skills } \\
\text { accumulating to } \\
\text { personal experience } \\
\text { with relevant } \\
\text { replicas. }\end{array}$ & $\begin{array}{l}\text { Skills by oneself to } \\
\text { greet, to say } \\
\text { goodbye, to refer to } \\
\text { and to respond to } \\
\text { them. Skills } \\
\text { according to a } \\
\text { mentor's model, to } \\
\text { make requests, } \\
\text { apologize, agree, } \\
\text { disagree, and } \\
\text { respond to them. }\end{array}$ & $\begin{array}{l}\text { Skills to apply } \\
\text { dialogical } \\
\text { replicas and } \\
\text { respond to } \\
\text { them on a given } \\
\text { topic. Skills to } \\
\text { accumulating } \\
\text { personal } \\
\text { experience with } \\
\text { relevant } \\
\text { replicas. }\end{array}$ & $\begin{array}{l}\text { Skills according to a mentor's } \\
\text { model, to greet (at different times } \\
\text { of the day), to express greetings, } \\
\text { wishes, acceptance, sympathy } \\
\text { and respond to them. } \\
\text { Skills to accumulating personal } \\
\text { experience with relevant replicas. }\end{array}$ \\
\hline \multicolumn{5}{|c|}{ Understanding the social roles and using in forms of communication } \\
\hline 2. & $\begin{array}{l}\text { An active sharing of } \\
\text { examples of using } \\
\text { the replicas in } \\
\text { relationships "child } \\
-\quad \text { child" in the } \\
\text { "family" } \\
\text { environment by } \\
\text { time "here and } \\
\text { now". } \\
\text { conversation Game, }\end{array}$ & $\begin{array}{l}\text { An active sharing of } \\
\text { examples of using } \\
\text { the replicas in } \\
\text { relationships "child } \\
\text { - child", "child - } \\
\text { adult" in the } \\
\text { "family", "class" } \\
\text { environment by } \\
\text { time "here and } \\
\text { now". } \\
\text { Game, } \\
\text { conversation, } \\
\text { staging. }\end{array}$ & $\begin{array}{l}\text { An active } \\
\text { sharing of } \\
\text { examples of } \\
\text { using the } \\
\text { replicas in } \\
\text { relationships } \\
\text { "child - child", } \\
\text { "child - adult } \\
\text { (close, alien)" } \\
\text { in the "family", } \\
\text { "class", } \\
\text { "street" } \\
\text { environment. } \\
\text { Present and }\end{array}$ & $\begin{array}{l}\text { An active sharing of examples of } \\
\text { using the replicas in relationships } \\
\text { "child - child", "child - adult } \\
\text { (close, alien)" in the "family", } \\
\text { "class", "street" environment etc. } \\
\text { Present and past tenses. Game, } \\
\text { conversation, educational hour }\end{array}$ \\
\hline
\end{tabular}




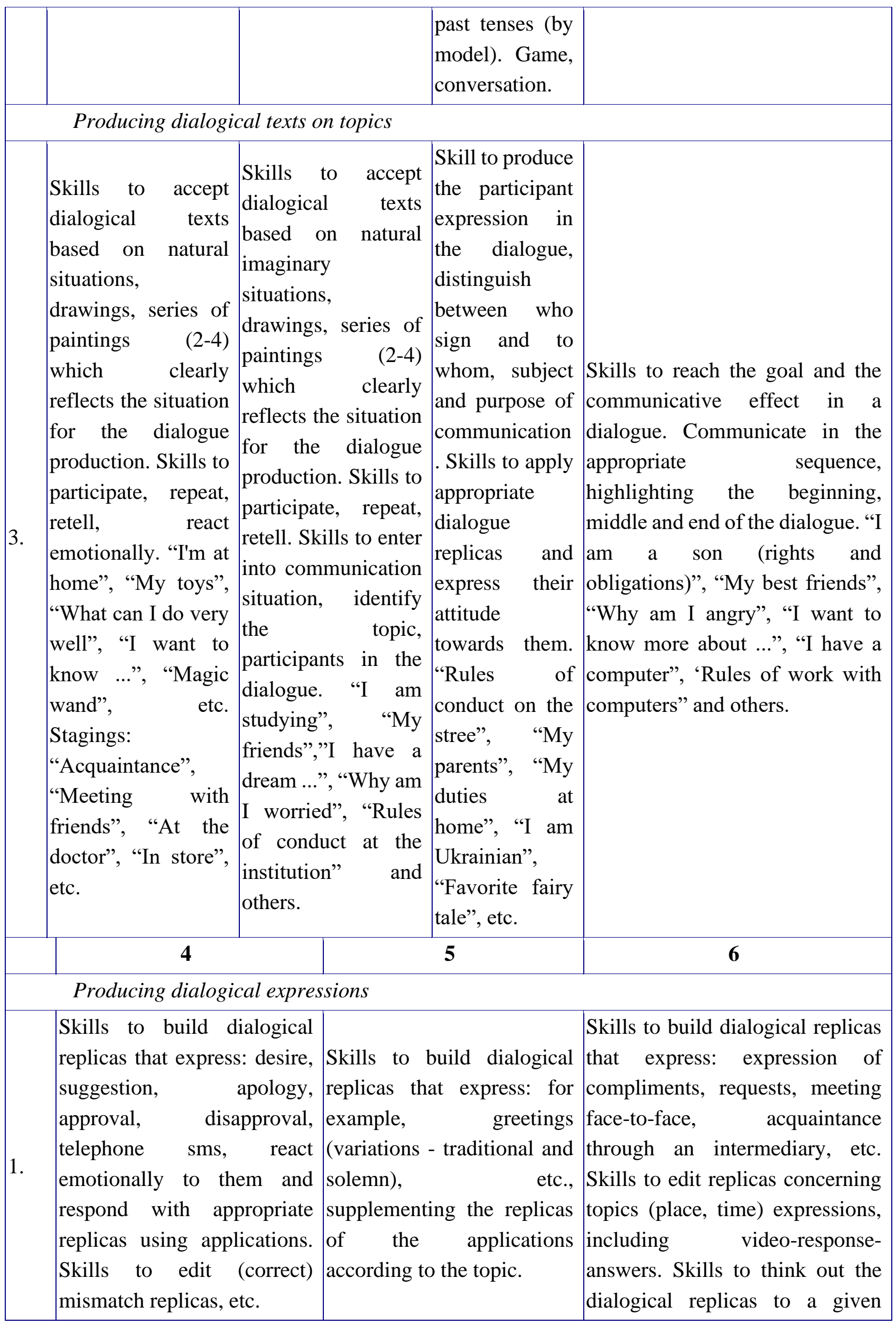




\begin{tabular}{|c|c|c|c|}
\hline & & & $\begin{array}{l}\text { situation, artificially created } \\
\text { or/and natural. }\end{array}$ \\
\hline \multicolumn{4}{|c|}{ Understanding the social roles and using in forms of communication } \\
\hline 2. & $\begin{array}{l}\text { An active exchanging } \\
\text { examples of the using } \\
\text { replicas in the relations "I - a } \\
\text { friend", "I - my parents" in } \\
\text { the institution environment, } \\
\text { outside the institution. Using } \\
\text { phrases of the speech } \\
\text { etiquette according to the } \\
\text { situation of communication } \\
\text { when making replicas. } \\
\text { Conversation, staging, role- } \\
\text { playing game, debate, class } \\
\text { hour, brainstorming. }\end{array}$ & $\begin{array}{l}\text { An active exchanging } \\
\text { examples of the using } \\
\text { replicas in the relations "I - } \\
\text { a friend", "I - my parents" } \\
\text { in the institution } \\
\text { environment, outside the } \\
\text { institution. Conversation, } \\
\text { debate, class hour, } \\
\text { brainstorming. }\end{array}$ & $\begin{array}{l}\text { An active exchanging examples } \\
\text { of the using replicas in the } \\
\text { relations "I - an acquaintance } \\
\text { (acquaintances)", "I - a stranger" } \\
\text { outside the institution. } \\
\text { Conversation, debate, class hour, } \\
\text { business game, brainstorming. }\end{array}$ \\
\hline \multicolumn{4}{|c|}{ Producing dialogical texts on topics } \\
\hline 3. & $\begin{array}{l}\text { Accumulation of skills to } \\
\text { communicate on the } \\
\text { principles of equality, } \\
\text { humanism, tolerance, } \\
\text { integrity, using respectful } \\
\text { appeal; formation of a } \\
\text { cultural behavior during } \\
\text { communication. "My free } \\
\text { time", "My feelings in } \\
\text { separation from relatives", } \\
\text { "If I were ..." "Relationships } \\
\text { in the family", "The world } \\
\text { around me" "Your classmate } \\
\text { - your friend". }\end{array}$ & $\begin{array}{l}\text { Formation skills and culture } \\
\text { communication in solving } \\
\text { cognitive tasks. "Who am I } \\
\text { in my family", "Family } \\
\text { members' responsibilities", } \\
\text { "Me and my friends", } \\
\text { "Ethics of sms-message", } \\
\text { "The world is a cruel, the } \\
\text { world is friendly", "If the } \\
\text { sorcerer comes ..." }\end{array}$ & $\begin{array}{l}\text { Formation experience and culture } \\
\text { communication in solving } \\
\text { cognitive tasks. "Difficulties in } \\
\text { communicating with teachers", } \\
\text { "Making rules for } \\
\text { communication } \\
\text { acquaintances (strangers)", "I am } \\
\text { a person", "Secure network } \\
\text { communication capabilities". }\end{array}$ \\
\hline & 7 & 8 & 9 \\
\hline \multicolumn{4}{|c|}{ Producing dialogical replicas } \\
\hline 1. & $\begin{array}{l}\text { Skills to constract dialogical } \\
\text { replicas expressing: various } \\
\text { kinds of wishes, approval, } \\
\text { face to face acquaintance, } \\
\text { through an intermediary, etc. } \\
\text { Skills to coordinate replicas } \\
\text { by participants (two - many). } \\
\text { Skills to think out the }\end{array}$ & $\begin{array}{l}\text { To constract dialogical } \\
\text { replicas of different types } \\
\text { that express: the skills to } \\
\text { adhere to a certain form and } \\
\text { the requirements of } \\
\text { language etiquette for } \\
\text { various types of } \\
\text { communication (telephone, }\end{array}$ & $\begin{array}{l}\text { To create dialogical replicas of } \\
\text { official-business style and reply } \\
\text { to them. The skills to control the } \\
\text { psycho-emotional state (own and } \\
\text { other), pauses, understanding the } \\
\text { peculiarities of intercourse } \\
\text { perception during video } \\
\text { interviews. }\end{array}$ \\
\hline
\end{tabular}




\begin{tabular}{|c|c|c|c|}
\hline & $\begin{array}{l}\text { dialogical replicas to a a } \\
\text { specific given situation. }\end{array}$ & $\begin{array}{l}\text { Skype, etc.) by focusing on } \\
\text { a certain topic. }\end{array}$ & \\
\hline \multicolumn{4}{|c|}{ Understanding the social roles and using in forms of communication } \\
\hline 2. & $\begin{array}{l}\text { An active exchanging } \\
\text { examples of the using } \\
\text { replicas in the relations "I - a } \\
\text { friend, friends", "I - } \\
\text { coevals" in the institution } \\
\text { environment, outside the } \\
\text { institution, in cultural } \\
\text { institutions. Conversation, } \\
\text { debate, class hour, role- } \\
\text { playing game, } \\
\text { brainstorming. }\end{array}$ & $\begin{array}{l}\text { An active exchanging } \\
\text { examples of the using } \\
\text { replicas in telephone, skype } \\
\text { relations "I - a friend", "I - } \\
\text { like-minded people" outside } \\
\text { the institution. } \\
\text { Conversation, debate, class } \\
\text { hour, business game, } \\
\text { brainstorming. }\end{array}$ & $\begin{array}{l}\text { An active exchanging examples } \\
\text { of the using replicas in the } \\
\text { relations "I'm on the Internet", "I } \\
\text { - my close", "I - strangers" in the } \\
\text { institution environment, outside } \\
\text { the institution. }\end{array}$ \\
\hline \multicolumn{4}{|c|}{ Producing dialogical texts on topics } \\
\hline 3. & $\begin{array}{l}\text { Application of effective } \\
\text { communication } \\
\text { organizational rules, } \\
\text { appropriate templates and } \\
\text { their motivated practical use } \\
\text { "Conflict - is ...", "Similarity } \\
\text { and dissimilarity of people", } \\
\text { "Causes of problems in peers } \\
\text { relations", "Feeling guilty", } \\
\text { "Carrying out of own leisure: } \\
\text { for and against' and others. }\end{array}$ & $\begin{array}{l}\text { Skills to establish, debug, } \\
\text { maintain contact between } \\
\text { the interlocutors; skills of } \\
\text { learning each other during } \\
\text { the exchanging of } \\
\text { information and emotions in } \\
\text { order to understanding and } \\
\text { regulating their own } \\
\text { behavior "Behavior can be } \\
\text { managed", "Ways of } \\
\text { avoiding problems", "My } \\
\text { Lifestyle", "Rules of own } \\
\text { life", etc. }\end{array}$ & $\begin{array}{l}\text { Knowledge of various } \\
\text { organizational } \\
\text { communication patterns during a } \\
\text { thematic dialogue and skills to } \\
\text { apply them successfully "What is } \\
\text { harmful to the human body", "I } \\
\text { am in a company", "Features of } \\
\text { the person's character", } \\
\text { "Working on presentability", } \\
\text { "Rules of communication in the } \\
\text { Internet", etc. Applying the } \\
\text { effective techniques } \\
\text { transitions/retreat. }\end{array}$ \\
\hline & 10 & 11 & 12 \\
\hline \multicolumn{4}{|c|}{ Producing dialogical replicas } \\
\hline 1. & $\begin{array}{l}\text { Build dialogical replicas of } \\
\text { domestic, official-business } \\
\text { style using the appropriate } \\
\text { appeals and reply on them. } \\
\text { Skills to control the distance } \\
\text { of the interlocutors. Skills to } \\
\text { build dialogical replicas that } \\
\text { express the speaker's } \\
\text { personal ideas within the } \\
\text { relevant subject area. }\end{array}$ & $\begin{array}{l}\text { Skills to build dialogic } \\
\text { replicas that express the } \\
\text { desire and need to invent, } \\
\text { evaluate and select ideas in } \\
\text { order to meet personal } \\
\text { communicative intentions, } \\
\text { also, to choose the form that } \\
\text { most successfully meets the } \\
\text { audience and goals. }\end{array}$ & $\begin{array}{l}\text { Skills to apply different samples } \\
\text { of dialogical replicas of the } \\
\text { appropriate styles, taking into } \\
\text { account the place, time, } \\
\text { peculiarities of perception, tasks } \\
\text { and needs of the audience. }\end{array}$ \\
\hline
\end{tabular}




\begin{tabular}{|c|c|c|c|}
\hline & $\begin{array}{l}\text { An active exchanging } \\
\text { examples of the using } \\
\text { replicas in normal and } \\
\text { conflicting relations "I - a } \\
\text { friend, friends", "I - } \\
\text { coevals" in the institution } \\
\text { environment, outside the } \\
\text { institution. Debate, training, } \\
\text { staging. }\end{array}$ & $\begin{array}{l}\text { An active exchanging } \\
\text { examples of the using } \\
\text { replicas, making rules of } \\
\text { conduct in the relations "I - } \\
\text { adults (deaf, hearing)", "I - } \\
\text { coevals" in the institution } \\
\text { environment, outside the } \\
\text { institution, in cultural } \\
\text { institutions. Debate, } \\
\text { training, staging. }\end{array}$ & $\begin{array}{l}\text { Active enrichment } \\
\text { communication by behavior } \\
\text { patterns and examples of the } \\
\text { using the replicas in relationships } \\
\text { "I - adults (deaf, hearing)", "I - } \\
\text { coevals" in the institution } \\
\text { environment, outside the } \\
\text { institution, in cultural } \\
\text { institutions. Debate, training, } \\
\text { staging, philosophy table. }\end{array}$ \\
\hline \multicolumn{4}{|c|}{ Producing dialogical texts on topics } \\
\hline o. & $\begin{array}{l}\text { The development of } \\
\text { productive leadership, } \\
\text { partnerships, tolerant } \\
\text { dialogue skills. Skills to } \\
\text { resolve conflicts. "My duties } \\
\text { in the family", "Article } 172 \\
\text { of the Family Code of } \\
\text { Ukraine", "Natural potential } \\
\text { of health". }\end{array}$ & 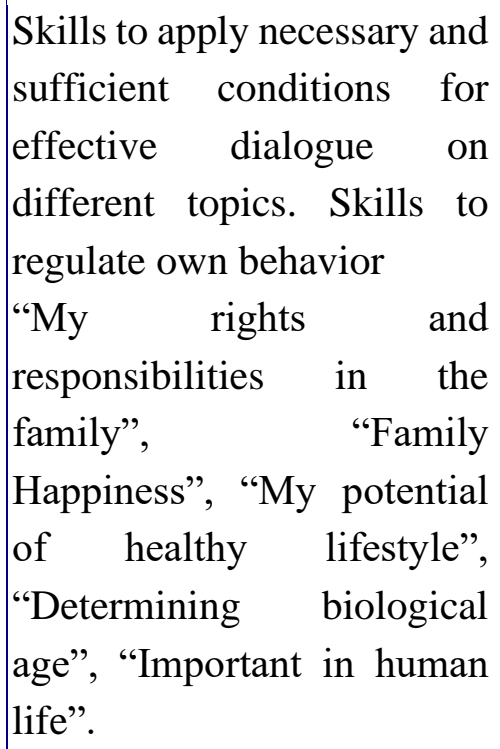 & $\begin{array}{l}\text { Skills to tolerant communication, } \\
\text { readiness to understand, go } \\
\text { towards, etc. Skills to calm down } \\
\text { emotions, defend your own } \\
\text { positions. To treat with } \\
\text { understanding to other positions } \\
\text { "My duties of a citizen", "Article } \\
172 \text { of the Family Code of } \\
\text { Ukraine", "Healthy person - who } \\
\text { is this?" }\end{array}$ \\
\hline
\end{tabular}

The use of the sign-speaking communicative competence model is important for the formation of not only communicative, but also gradual strategies for the development of cognitive activity:

a) learning as an imitation of a mentor (involves mastery of practical skills);

b) learning as a process of transferring mentor's knowledge to students (introduces situations, facts, rules, specific examples);

c) learning as a process of thinking formation (working out the active interaction of a deaf student as a subject of communicative-cognitive activity). Therefore, the student, with the help of a mentor, learns to produce his own statements, to formulate opinions accurately, to apply the necessary linguistic means of language, to master samples to be able to reasonably defend their own position; to understand and to report who is right and who is wrong. It is important that the student recognizes the right to 
personal views, the presentation of ideas and the ability to correct them as a result of critical analysis.

In the process of choosing a strategy should be considered the factor of the coefficient of utility and disadvantages of each, to focus on the model of the student with his lower level competencies. Accordingly, some strategies and pedagogical technologies place emphasis on display and imitation, the second - on explanation and conscious assimilation, the third - on stimulating the student's independent research activity, the fourth - on the organization of communicative activities.

It should be noted, that according to the peculiarities of competence education, an important role is assigned to the independent research activity of a deaf student. In fact, independence today should be considered not only as a student's ability to search for answers, to read, to analyze and to generalize, but also to make decisions, to take responsibility for its effectiveness, to consciously control their real and possible actions, to constantly analyze and to evaluate them.

In the modern practice of special institutions of general secondary education for the deaf, some experience in forming S-SCC in communicative activities is gradually accumulating. An important role in the formation of competencies belongs to the mentor. Each mentor is a scriptwriter and director of each lesson or class. We would like to note the experimental institutions and teachers who took an active part in the implementation of research results: Multidisciplinary Training and Rehabilitation Center "Constellation" in Kryvyi Rih city Dniprovsky region (L. Kolomoyets, L. Lutsenko, O. Kasetska, S. P'yatnychko, O. Bilanova); Terebovlya Training and Rehabilitation Center in Ternopil region (M. Katsan, O. Schutska, D. Kapelyuh, O. Lomakina, O. Stetsula, M. Paliy, P. Rod', V. Schutsky and others); Secondary Education Institution of II-III Degrees “Evening (shift) special school № 27” in Kyiv city (Sadova, Fedorchenko \& Muzhaylo, 2017). Although, it should be noted that many practitioners have some difficulties in optimal choice of strategies, techniques, means of bilingual communicative activities, their system of combination and systematic using. It seems that coordinated work should be carried out to explain the principles of bilingualism competence with a clear understanding of the role, significance and place 
of sing-speaking communicative competence in the system of surdopedagogic activity, paying special attention to the first five years of life of a deaf child.

\section{CONCLUSIONS}

At the national level, there have been changes caused by information from near and far abroad on the positive experience of using bilingual curricula as a consequence of improving the quality of the educational development of the deaf, which created the need for a rethinking of the role of monolingualism, bilingualism (Ukrainian language and Ukrainian sign language) for deaf people, and developing on this basis key competencies during school education. S-SCC is considered as a key competence in order to match its current developments with Ukrainian scholars. There is an urgent need to consolidate the bilingual approach in the legal and regulatory framework (the Law "On Education", the Regulations on the Special School and the Training and Rehabilitation Center) and reflect the changes in the educational realities of special and inclusive institutions.

Bilingualism with the use of the components of the lingvodactic model of S-SCC should be practical, because it is based on the resources of two languages, which are considered not as a problem, but as a resource for enrichment, taking into account the capabilities, abilities of each deaf student.

Experience has shown that the favorable educational discourse of experimental institutions of special education in applying the bilingual approach, the commitment of individual teachers who use USL, representatives of public organizations UTOG, Association of the Deaf teachers who promote and contribute to the implementation of the bilingual approach.

Prospects for further research we see not only in the development of linguodidactic basics of bilingualism, methodological developments of scholars, practitioners, teaching technologies in accordance with age characteristics, but also in the revision of the professional training of surdo-pedagogues, surdo-psychologists, communication specialists, sign language interpreters in order to learn the linguistic 
awareness and acquire communicative strategies for supporting deaf students in different conditions (family, group, class), leading activities.

\section{REFERENCES}

Bauman, H-D. (Ed.). (2008). Open Your Eyes: Deaf Studies Talking. University of Minnesota Press. Baykina, N., \& Kulbida S. (2014). Movne zabezpechennya korektsiynogo protsesu na navchalnotrenuvalnyh zanyattyah iz gluhymy pidlitkamy [Linguistic support of the correction process at training sessions with deaf teenagers]. In Indyvidualni metodyky adaptyvnoi fizychnoi kultury dlya osib iz sensornymy porushennyamy: navchalnyy posibnyk (pp. 303-425) [Individual methods of adaptive physical culture for persons with sensory impairments: tutorial]. Zaporizhzhya: Zaporizhzhia National University.

Chamberlain, C., \& Mayberry, R. (2008). American Sign Language syntactic and narrative comprehension in skilled and less-skilled readers: Bilingual and bimodal evidence for the linguistic basis of reading. Appl Psycholinguist, 29 (3), 367-388.

Chepchyna, I. I. (2018). Novi zakonodavchi initsiatyvy u svitli zastosuvannya ukrayinskoyi zhestovoyi movy [New legislative initiatives in the light of using Ukrainian Sign Language]. In Teoretychne $i$ metodychne zabezpechennya navchannya ta vykhovannya osib z osoblyvymy osvitnimy potrebamy (pp. 242-246) [Theoretical and methodological support of training and education persons with special educational needs]. Slovyansk: DDPU. Retrieved 2019 from: http://lib.iitta.gov.ua/711725

Czubek, T. (2007). Bilingual Education and Deaf Children. Proceedings from: The Learning Center for Deaf Children Training Seminar. Framingham, MA.

Czubek, T. (2009). Connecting, Collaborating and Celebrating ASL \& English. Proceedings from California Deaf Educators Conference. San Diego, CA.

Dymskys, L. (2008). Izuchaem zhestovyy yazuk [Learn sign language]. Moscow: Akademiya.

Humphries, T., Kushalnagar, P., Mathur, G., Napoli, D., Padden, C., Rathmann, C., \& R Smith, S. (2012). Language acquisition for deaf children: Reducing the harms of zero tolerance to the use of alternative approaches. Harm Reduction Journal, 9. https://doi.org/10.1186/1477-7517-9-16

Ivanyusheva, N. \& Kulbida, S. (2013). Osoblyvosti zastosuvannya dvomovnykh prohram yak instrument zberezhennya movy linhvistychnoyi menshyny [Features of using bilingual programs as a tool for preserving the language of the linguistic minority]. In Osvita osib z osoblyvymy potrebamy: shlyakhy rozbudovy: zbirnyk naukovyh prats (pp. 25-33) [Education of persons with special needs: ways of development: collection of scientific works]. Kirovohrad: Imeks-LTD. Retrieved 2019 from http: //www.irbis-nbuv.gov.ua

Kobel, I. (2005). Pidkhid «dvi movy - dvi kul'tury»: chy vykorystannya zhestovoyi movy spryyaye rozvytkovi hramotnosti u hlukhykh ditey? [The approach of "two languages - two cultures", or does using of sign language promotes literacy in deaf children?]. Proceedings from Mizhnarodnoyi konferentsiyi Ukrayins'ko-kanads'kyy dosvid. Kyiv-Edmonton, 89-98.

Krausneker, V. (2008). The protection and promotion of sign languages and the rights of their users in Council of Europe member states: Needs analysis. Strasbourg, FR: Council of Europe, Retrieved 2019 from https://www.ecml.at/Portals/1/documents/CoEdocuments/The protection_and_promotion_sign_language_eng.pdf.pdf

Krayevskyy, R. (1964). Mova zhestiv hlukhykh [Sign Language of the Deaf]. Kyiv: Radyans'ka shkola.

Kremen, V. (2008). Filosofiya lyudynotsentryzmu v stratehiyakh osvitn'oho prostoru [Philosophy of human-centrism in strategies of educational space]. Kyiv: Pedahohichna dumka.

Kulbida, S. (2016). Formuvannya zhestomovnoi komunikatyvnoi kompetentsii - vid rozuminnya do zastosuvannya [Formation of oral communicative competence - from understanding to 
application]. In Osoblyva dytyna: navchannya $i$ vyhovannya, 1/77, 15-29. Retrieved 2019 from http://lib.iitta.gov.ua/707090/

Kulbida, S. (2018). Introduction features of bilingual Education of deaf People in Ukraine. Proceedings from Osvita vprodovzh zhyttya: sotsialni zapyty, suchasni vyklyky ta pryoritety $v$ realizatsii. Kyiv: NAU, 140-150. Retrieved 2019 from: http://lib.iitta.gov.ua/710550/

Kulbida, S., \& Chepchyna, I. (2009). Proekt contseptsii zhestovoi movy v Ukraini [Draft Concept of Sign Language in Ukraine]. Defectologiya, 3, 3-7. Retrieved 2019 from http://lib.iitta.gov.ua/706187/ (in Ukrainian).

Leal, C. (2005). Inclusive education and bilingualism. Good practices and progress from Spain. Programme and Abstract Book of the 20th Congress of the Education of the Deaf, 156. Maastricht: ICED. 21.

Malynovych, L. (2009). Nastupnist v roboti doshkilnoho zakladu i shkoly. [Continuity in the work of preschool and school]. In Zbirnyk materialiv Vseukrayins'kykh KH yuvileynykh chytan' z problemy «Surdopedahohichna nauka yak skladova Yevropeys'koyi tsyvilizatsiyi» (pp. 74-81) [Collection of materials of the All-Ukrainian jubilee readings on the problem "Surdo-pedagogy as a component of European civilization"]. Kyiv.

Mamchur, L. (2012). Perspektyvnist i nastupnist u formuvanni komunikatyvnoyi kompetentnosti uchniv osnovnoyi shkoly: monohrafiya [Perspective and continuity in the formation of communicative competence of secondary school students: monograph]. Uman: "Sochins'kyy".

Mason, D. G. (1995). Why bilingualism/biculturalism is appropriate in deaf education. DCS newsletter of Deaf Children's Society of British Columbia.

Ministry of Education and Science of Ukraine. (2016). Kontseptsiya novoi ukrainskoi shkoly [Concept of New Ukrainian School]. Retrieved 2019 from https://mon.gov.ua/ua/tag/novaukrainska-shkola

Ministry of Education and Science of Ukraine. (2019). Pro zatverdzhennya Polozhennya pro spetsial'nu shkolu ta Polozhennya pro navchal'no-reabilitatsiynyy tsentr [On approval of the Regulations on the special school and training and rehabilitation center]. Retrieved 2019 from https://zakon.rada.gov.ua/laws/show/221-2019-\%D0\%BF

Padden, C., \& Ramsey, C. (2000). American Sign Language and reading ability in deaf children. In C. Chamberlain, J. Morford, R. Mahwah Mayberry (Ed.), Language Acquisition by Eye (pp. 165-189) NJ: Earlbaum,

Sadova, A. P., Fedorchenko, D. A., \& Muzhaylo, I. S. (2017). Programs of the Ukrainian Sign Language. 8-11 forms. S. Kulbida (Ed.). Kyiv.

Schick, B. (2003). The development of American Sign Language and manually coded English systems. The Handbook of Deaf Studies, Language, and Education. M. Marschark, P. Spencer (Ed.). Oxford: Oxford University Press.

Stewart, D., \& Clarke, B. (2003). Literacy and Your Deaf Child: What Every Parent Should Know. Washington: Gallaudet University Press.

Tkachenko, K., \& Kulbida, S. (2014). Orhanizatsiyno-metodychni umovy diyal'nosti kabinetu ukrayinskoyi zhestovoyi movy u zahalnoosvitnikh spetsialnykh zakladakh dlya nechuyuchykh uchniv [Organizational and methodological conditions of the Ukrainian Sign Language classroom activity in special educational institutions for deaf students]. In Osvita osib z osoblyvymy potrebamy: shlyakhy rozbudovy (pp. 72-84) [Education for people with special needs: ways to develop]. Kirovograd: Imeks-LTD. Retrieved from http://lib.iitta.gov.ua/707200/

Wilbur, R. (2001). Sign language and successful bilingual development of deaf children. J Inst Social Res. 56: 1039-1079.

Zakon Ukrainy "Pro osvitu” [Law of Ukraine “On Education"].(2017). Retrieved 2019 from http://zakon.rada.gov.ua/laws/show/2145-19

Zasenko, V. (2015). Osoblyvi dity: osvita ta suprovid [Special children: education and support]. Svitohliad, 4, 12-15. 
Zaytseva, G. (2000). Sign Language. Sign Language Alphabet: Textbook for university students. Moscow: VLADOS. 